Artikel Riset

DOI : 10.33751/jf.v8i2.1574
Fitofarmaka Jurnal Ilmiah Farmasi

Vol. 8, No.2, Desember 2018

p-ISSN : 2087-9164 e-ISSN : 2622-755X

\title{
AKTIVITAS ANTIOKSIDAN DAN KANDUNGAN SERAT PANGAN BISKUIT CAMPURAN BEKATUL BERAS MERAH (Oriza glaberrima) DAN UBI JALAR UNGU (Ipomoea batatas)
}

\author{
Cantika Zaddana, Mira Miranti, Almasyhuri dan Siti Tanzila \\ Program Studi Farmasi FMIPA UNPAK - Bogor \\ Email: cantikazaddana@gmail.com
}

Disetujui : 23 Desember 2018

\begin{abstract}
ABSTRAK
Bekatul beras merah (Oriza glaberrima) dan ubi jalar ungu (Ipomoea batatas) memiliki aktivitas antioksidan yang berasal dari senyawa fenolik dan antosianin yang terkadung didalamnya. Penggunaan ubi jalar ungu dikombinasikan dengan bekatul beras merah pada formulasi biskuit diharapkan dapat meningkatkan kualitas gizi dan kandungan serat biskuit tersebut. Penelitian ini bertujuan untuk menentukan formula biskuit dari campuran bekatul beras merah dan ubi jalar ungu yang memiliki aktivitas antioksidan paling tinggi dan rasa disukai panelis. Parameter yang digunakan dalam penelitian ini adalah daya terima panelis, aktivitas antioksidan, kandungan serat pangan, dan kandungan proksimat. Hasil analisis menunjukkan tidak ada pengaruh perbedaan formula terhadap parameter warna, rasa dan aroma. Hasil uji aktivitas antioksidan diperoleh bahwa Formula 1 dengan perbandingan bekatul beras merah : ubi jalar ungu (20:40) memiliki aktivitas antioksidan yang paling tinggi dengan nilai IC $_{50}$ pada 106,349 ppm, kadar serat sebesar 6,38\%, kadar protein sebesar 6,92\%, kadar air sebesar 2,52 \%, kadar abu sebesar 1,45\%, kadar lemak sebesar 16,178\%, dan kandungan karbohidrat sebesar $72,562 \%$.
\end{abstract}

Kata kunci: Bekatul beras merah, ubi jalar ungu, aktivitas antioksidan, serat pangan

\section{ANTIOXIDANT ACTIVITY AND FIBER CONTENT OF BISCUIT MADE FROM RED RICE BRAN AND PURPLE YAM}

\begin{abstract}
Red rice bran (Oriza glaberrima) and purple yam (Ipomoea batatas) have antioxidant activity associated with the high phenolic and anthocyanin compounds found in grain and tuber of these plants. The combination of red rice bran and purple yam to formulate biscuit was expected to enhance the nutrition value fiber content of the biscuit. This study was aimed to formulate biscuit using combination red rice bran and purple yam with highest antioxidant activity and most preferable taste. The parameters measured were organoleptic/palatabilites, antioxidant activity, dietary fiber content, and proximate assays. The results show that the formula difference has no significant effect on organoleptic parameters as color, taste and flavor of biscuit. All formulated red rice bran and purple yam biscuit were well accepted by panelists. Formula 1, combination of red rice bran: purple yam with the ratio 20:40 found the be the best formula with highest antioxidant activity $\left(\mathrm{IC}_{50}\right.$ at $\left.106.349 \mathrm{ppm}\right), 6.38 \%$ fiber, $6.92 \%$ protein, $2.52 \%$ water, $1.45 \%$ ash, $16.178 \%$ fat and $72.562 \%$ carbohydrate
\end{abstract}


content.

Keywords: Ipomoea batatas, Oriza glaberrima, antioxidant activity, dietary fiber

\section{PENDAHULUAN}

Pangan fungsional adalah pangan yang mengandung satu atau lebih komponen fungsional yang berdasarkan kajian ilmiah mempunyai fungsi fisiologis tertentu, terbukti tidak membahayakan dan bermanfaat bagi kesehatan. Pangan fungsional dapat berupa makanan ataupun minuman yang diolah maupun tidak diolah (BPOM, 2005). Beberapa senyawa yang dapat memberikan efek fisiologis tersebut adalah antioksidan dan serat pangan, kedua senyawa tersebut dapat ditemukan pada bekatul beras merah dan ubi jalar ungu. Antioksidan diperlukan oleh manusia untuk menangkal radikal bebas di dalam tubuh. Senyawa tersebut mempunyai struktur molekul yang dapat memberikan elektronnya dengan mudah kepada molekul radikal bebas tanpa mengganggu fungsinya, dan dapat memutus reaksi berantai dari radikal bebas. Salah satu jenis antioksidan adalah yang diperoleh dari bahan alam (Kumalaningsih, 2007).

Serat pangan (dietary fibre) mencakup seluruh bagian tanaman yang tidak dapat dicerna oleh enzim pencernaan manusia, tanpa membedakan serat tersebut mengalami atau tidak mengalami proses pengolahan, tanpa melihat untuk kepentingan diet tanpa mempertimbangkan serat tersebut bisa atau tidak untuk dimakan. Kebutuhan serat pangan harian yang dianjurkan sebesar 30 gram/hari. (Marsono, 1996).

Bekatul memiliki beberapa jenis diantaranya bekatul beras putih, bekatul beras merah, bekatul beras hitam, dan lain-lain. Menurut hasil penelitian Tengah et al., (2011), bekatul beras merah memiliki kandungan senyawa fenolik dan antosianin yang membuat bekatul beras merah berpotensi sebagai sumber antioksidan alami. Semakin tinggi kandungan fenolik dan antosianinnya maka nilai $\mathrm{IC}_{50}$ semakin baik. Diketahui nilai $\mathrm{IC}_{50}$ pada bekatul beras merah Cendana adalah 21,98 $\mathrm{mL}$ ekstrak/g DPPH, total fenolik sebesar 4,38 mg/100g bekatul, dan kadar antosianin 109,33 $\mathrm{mg} / 100 \mathrm{~g}$ bekatul. Semakin kecil nilai $\mathrm{IC}_{50}$ maka semakin aktif zat tersebut sebagai antioksidan, maka aktivitas antioksidan pada bekatul beras merah Cendana ini tergolong sangat aktif. Moko et. al. (2014) dalam hasil penelitiannya menyebutkan bahwa bekatul dari beras yang berpigmen lebih banyak memiliki sifat antioksidan dibandingkan dengan bekatul yang berasal dari beras tidak berpigmen, disebutkan pula nilai $\mathrm{IC}_{50}$ beras berpigmen 26,26 $\mu \mathrm{g} / \mathrm{mL}$, sedangkan beras yang tidak berpigmen nilai $\mathrm{IC}_{50}$ berkisar antara 363,17 - 341,88 $\mu \mathrm{g} / \mathrm{mL}$.

Ubi jalar ungu merupakan salah satu jenis ubi yang memiliki pigmen antosianin sehingga membuat warna daging dan kulitnya berwarna ungu. Produknya telah beragam, banyak diproduksi menjadi tepung agar. Masa penyimpanannya bisa lebih panjang dan mudah digunakan dalam berbagai produk olahan. Tepung ubi jalar ungu dapat digunakan untuk substitusi tepung terigu $10-50 \%$ pada produk mi, roti, cookies, cake, dan eskrim (Gardjito et al., 2013). Serat pangan yang terkandung dalam tepung ubi jalar ungu adalah $4,45 \%$, di mana kandungan serat ini dapat membantu menyumbang kebutuhan serat harian. Ubi jalar ungu masih bisa digunakan sebagai bahan pewarna makanan alami dan penambah zat gizi karena adanya kandungan vitamin dan mineral, antara lain adalah zat besi $(\mathrm{Fe})$, fosfor $(\mathrm{P})$, kalsium $(\mathrm{Ca})$, vitamin $\mathrm{A}$, vitamin $\mathrm{B}$, dan ribovalvin (Kumalaningsih, 2007).

Biskuit adalah makanan praktis dan dapat dimakan dimana saja, selain itu 
biskuit juga memiliki daya simpan yang relatif panjang (Manley, 2000). Bekatul beras merah dan tepung ubi jalar ungu ini dijadikan sebagai bahan baku pembuatan biskuit, dengan harapan kombinasi dari keduanya dapat membantu memberikan asupan nutrisi yang diperlukan oleh tubuh seperti antioksidan dan serat pangan yang terkandung di dalamnya. Formula yang digunakan merupakan reformulasi dari penelitian Wulandari dan Handarsari (2011), dimana pada formula ini terdapat penambahan kuantitas bahan, mengganti bekatul beras putih dengan bekatul beras merah, mengganti gula pasir dengan stevia sebagai pemanis, serta ditambahkan bahan lain seperti ubi jalar ungu dan perasa coklat agar rasanya dapat lebih disukai dan diterima oleh masyarakat.

\section{METODE PENELITIAN Waktu dan Tempat Penelitian}

Penelitian ini dilaksanakan pada bulan Juni sampai Agustus 2017 bertempat di Laboratorium Farmasi, Fakultas Matematika dan Ilmu Pengetahuan Alam Universitas Pakuan, Bogor.

\section{Alat dan Bahan}

Alat-alat yang digunakan dalam penelitian ini adalah timbangan analitik, oven, loyang tipis, cetakan kue, kertas saring, mixer, baskom, talenan, wadah, pengaduk, sendok, pengayak 80 mesh, cawan porselen, desikator, tanur $\left(\mathrm{Ney}^{\circledR}\right)$, soxhlet, kondensor, labu lemak, labu kjedahl, hot plate, dan alat-alat gelas lainnya yang digunakan untuk analisis.

Bahan-bahan utama yang digunakan dalam penelitian ini adalah bekatul beras merah yang diperoleh dari Pelabuhan Ratu dan ubi jalar ungu tua diperoleh dari Pasar Pelita Sukabumi.

Bahan tambahan lainnya adalah tepung terigu, susu skim bubuk, margarin, sebutir kuning telur, sukralosa, dan bahan kimia yang digunakan untuk analisis adalah etanol 95\%, magnesium, asam klorida, Bouchardat LP, Mayer LP, Dragendorff LP, akuades, besi (III) klorida, natrium klorida, selenium, asam sulfat pekat, natrium hidroksida, larutan indikator (cairan methyl red dan brom creosol green), asam borat, heksana, asam nitrat, asam klorat, kalsium karbonat, ammonium molibdat, potassium dihidrogen fosfat, larutan baku natrium.

\section{Pembuatan Bekatul Beras Merah}

Bekatul beras merah digiling dan diayak dengan ayakan mesh 40 untuk memisahkan bagian yang halus dan yang kasar termasuk sekam. Tepung bekatul halus kemudian disangrai diatas api kecil sambil diaduk hingga kering tetapi tidak gosong selama 5 menit. Setelah kering diayak kembali dengan menggunakan ayakan mesh 40 .

\section{Pembuatan Tepung Ubi Jalar Ungu}

Tepung ubi jalar ungu dapat dibuat secara langsung dari ubi jalar yang diiris tipis dan dikeringkan, kemudian digrinder dan dihaluskan dengan ayakan dapur.

\section{Formulasi Olahan Biskuit}

Olahan biskuit dibuat menggunakan tiga formulasi berbeda seperti tercantum pada Tabel 1.

Tabel 1. Formula Bahan Pembuatan Olahan Biskuit

\begin{tabular}{lrrr}
\hline \multicolumn{1}{c}{ Komposisi } & \multicolumn{3}{c}{ Penambahan Bekatul (\%) } \\
\cline { 2 - 4 } \multicolumn{1}{c}{ Bahan } & \multicolumn{1}{c}{ F1 } & F2 & \multicolumn{1}{c}{ F3 } \\
\hline Tepung Terigu & 22,7 & 22,7 & 22,7 \\
Bekatul Beras & 11,2 & 8,7 & 5,5 \\
Merah & & & \\
& & & \\
Tepung Ubi & 22,5 & 25 & 28 \\
Jalar Ungu & & & \\
& & & \\
Kuning Telur & 15 & 15 & 15 \\
Margarine & 13,2 & 13,2 & 13,2 \\
Vanilli & 0,4 & 0,4 & 0,4 \\
Baking Soda & 0,4 & 0,4 & 0,4 \\
Cokelat bubuk & 1,8 & 1,8 & 1,8
\end{tabular}


$\begin{array}{llll}\text { Susu Skim } & 1,8 & 1,8 & 1,8\end{array}$

\begin{tabular}{llll} 
Stevia & 11,2 & 11,2 & 11,2 \\
\hline
\end{tabular}

\section{Pembuatan Biskuit}

Pembuatan biskuit dilakukan sesuai dengan prosedur Wulandari dan Handarsari (2010) yang terdiri dari tiga tahap pencampuran yaitu pertama pencampuran bahan seperti margarin, pemanis (gula, stevia, atau yang lainnya) dan susu dicampur dan diaduk menggunakan mixer selama 5 menit. Pencampuran ke dua ditambahkan kuning telur, dihomogenkan menggunakan mixer selama 10 menit. Pencampuran ke tiga ditambahkan bahan tepung terigu dan bekatul beras merah dan tepung ubi jalar ungu, kemudian dicampur sampai merata. Adonan yang sudah jadi dicetak menggunakan cetakan biskuit, setelah itu masuk ke proses pemanggangan selama 20-30 menit dengan suhu $150^{\circ} \mathrm{C}$.

\section{Uji Mutu Sediaan Biskuit Uji organoleptik}

Uji ini meliputi penilaian terhadap karakteristik sediaan kering yang meliputi warna, rasa dan aroma tepung kecambah kedelai dan kacang hijau.

\section{Uji Hedonik}

Uji kesukaan dilakukan terhadap 20 orang panelis, sebelumnya para panelis tidak mengkonsumsi makanan atau minuman yang dapat mempengaruhi penilaian. Para panelis diminta mencicipi untuk menilai rasa, aroma dan warna dari sampel sediaan biskuit. Para panelis diharapkan untuk mengisi kertas kuisioner yang telah disediaakan. Hasil dari uji hedonik dianalisis menggunakan SPSS.17 dengan metode RAL (Rancangan Acak Lengkap).

\section{Aktivitas Antioksidan Dengan Metode DPPH}

Pembuatan Larutan Blanko

Dipipet sebanyak $1 \mathrm{ml}$ larutan
DPPH $1 \mathrm{mM}$, ditambahkan metanol sampai $10 \mathrm{ml}$, kemudian dihomgenkan. Larutan blanko diinkubasi pada suhu sekitar $37^{\circ} \mathrm{C}$ selama 30 menit.

\section{Pembuatan Larutan Uji}

Sebanyak $100 \mathrm{mg}$ bekatul beras merah dihancurkan, kemudian dimasukan kedalam labu ukur $100 \mathrm{ml}$ dan diencerkan dengan metanol sampai batas (1000 ppm). Dibuat deret 20, 40, 60 dan $80 \mathrm{ppm}$. Untuk sediaan biskuit ditimbang berat setara yang telah dihitung yaitu F1 : 600mg ; F2 : 666,67 mg ; F3 : $1000 \mathrm{mg}$. Dibuat deret mulai dari 60, 80, 100, 120, 140, dan 160 ppm. Masing-masing labu ukur ditambah $1 \mathrm{ml}$ larutan DPPH $1 \mathrm{nM}$, selanjutnya diencerkan dengan metanol, dikocok dan diinkubasi pada suhu kamar selama waktu optimum. Serapan diukur pada panjang gelombang maksimum yang telah ditentukan.

\section{Uji antioksidan dengan larutan DPPH}

Deret larutan diuji, deret kontrol positif vitamin $\mathrm{C}$ dan blanko diukur serapanya pada panjang gelombang maksimum yang telah ditentukan.

Nilai $\quad \mathrm{IC}_{50} \quad$ (Iinhibitor concentrasion) diperoleh dari potongan garis antara $50 \%$ daya hambat dengan sumbu konsentrasi menggunakan persamaan linear $(y=b x+a)$, dimana $y=$ 50 dan x menunjukan $\mathrm{IC}_{50}$.

\section{Uji Proksimat \\ Uji kadar protein}

Sebanyak 1 gram cuplikan (untuk yang protein tinggi 0,3-0,5 gram) ditimbang seksama dan dimasukkan ke dalam tabung kjeldahl. Sebanyak 2 gram campuran selen dan $12 \mathrm{ml} \mathrm{H}_{2} \mathrm{SO}_{4}$ pekat. Digestion block dinyalakan kemudian didestruksi pada suhu $400^{\circ} \mathrm{C}$ selama 1 jam, setelahnya didinginkan dan dimatikan. Sampel sequence pada Kleltec dibuat dengan program dengan AN300, 
selanjutnya dipasang dan dijalankan sequence. Penetapan blanko dilakukan. Kadar Protein dapat dihitung dengan menggunakan persamaan (1)

$\mathrm{N}(\%)=\frac{(\mathrm{ml} \mathrm{HCl}-\mathrm{ml} \mathrm{HCl} \text { blanko }) \times \mathrm{N} \mathrm{HCl} \times 14.007}{\mathrm{mg} \mathrm{sampel}} \times 100 \%$

\section{Uji Kadar Lemak}

Pengujian kadar lemak dengan mengguanakan metode soxhlet. Sebanyak 2 gram sampel yang telah dihaluskan, kemudian dimasukan kedalam selongsong kertas yang telah dialasi dengan kapas, disumbat kertas berisi sampel tersebut dengan kapas keringkan dalam oven pada suhu lebih dari $80^{\circ} \mathrm{C}$ selama \pm 1 jam, kemudian dimasukan kedalam tabung ekstraksi soxhlet yang telah dihubungkan dengan labu lemak berisi batu didih yang telah dikeringkan dan diketahui beratnya. Ekstraksi dengan heksana atau pelarut lemak lainnya selama \pm 6 jam. Setelah itu, sulingkan heksana dan keringkan ekstrak lemak dalam oven pengeringan pada suhu $150^{\circ} \mathrm{C}$ selama 30 menit. Didinginkan dan ditimbang (pengeringan diulangi hingga bobot tetap). Kadar lemak yaitu lebih dari 7\% (DeKes RI, 1992). Kadar lemak dihitung dengan menggunakan persamaan (2).

$$
\text { Kadar lemak }(\%)=\frac{w 2-W_{1}}{w} \times 100 \%
$$

Keterangan :

$\mathrm{W}=$ Bobot sampel

$\mathrm{W} 1$ = Bobot labu lemak

$\mathrm{W} 2$ = Bobot labu + lemak setelah dioven

\section{Uji Kadar Karbohidrat}

Penetuan kadar karbohidrat dengan metode by difference kadar karbohidrat dapat ditentukan dengan menggunakan persamaan (3).

$\%$ karbohidrat $=$

$$
100 \%-(\mathrm{air}+\mathrm{abu}+\text { lemak }+ \text { protein })
$$

\section{Uji Kadar Air}

Cawan petri kosong dioven terlebih dahulu, lalu didinginkan dan ditimbang bobot kosongnya. Sejumlah sampel kurang lebih 3-5 gram dimasukan kedalam cawan yang telah diketahui beratnya. Kemudian cawan dimasukan kedalam oven bersuhu $100^{\circ} \mathrm{C}$ hingga diperoleh berat yang tetap (AOAC, 1995). Perhitungan kadar air dilakukan berdasarkan berat basah dengan menggunakan rumus :

$$
\text { Kadar Air }(\% \text { bb })=\frac{B-C}{B-A} \times 100 \%
$$

Keterangan :

$\mathrm{A}=$ Berat cawan kosong $(\mathrm{g})$

$\mathrm{B}=$ Berat cawan + sampel sebelum dikeringkan $(\mathrm{g})$

$\mathrm{C}=$ Berat cawan + sampel setelah dikeringkan $(\mathrm{g})$

\section{Uji Kadar Abu}

Dimasukan lebih kurang 2-3 gram sampel dalam krus silika yang telah dipijarkan dan ditara lalu diratakan. Dipijarkan perlahan-lahan hingga arang habis, dinginkan lalu ditimbang. Jika cara ini arang tidak dapat hilang, ditambahkan air panas, disaring melalui kertas saring bebas abu. Dipijarkan sisa kertas, diuapkan dipijarkan hingga bobot tetap, ditimbang. Hitung kadar abu terhadap bahan yang telah dikeringkan diudara (Depkes RI, 2000).

Kadar abu $(\%)=\frac{(\text { bobot krus }+a b u)}{\text { bobot awal sampel }} \times 100 \%$

\section{HASIL DAN PEMBAHASAN \\ Hasil Uji Mutu Biskuit Uji Organoleptik}

Hasil uji organoleptik ketiga biskuit yang telah dibuat memiliki bentuk yang sama yaitu persegi panjang, dengan warna coklat pekat dan pipih. Masing-masing biskuit memiliki karakteristik yang sama terhadap parameter warna dan aroma. Persamaan tersebut terjadi karena bahan baku yang digunakan sama, namun pada parameter rasa perbedaan konsentrasi antara bekatul beras merah dan ubi jalar ungu menimbulkan rasa yang sedikit berbeda. 
Perbedaan tersebut disebabkan oleh penambahan konsentrasi tepung jalar ungu pada setiap formula yang berbeda, semakin banyak konsentrasi yang ditambahkan maka akan semakin memberikan rasa manis pada biskuit. Hasil uji organoleptik terdapat pada Tabel 2 dan Gambar 1.

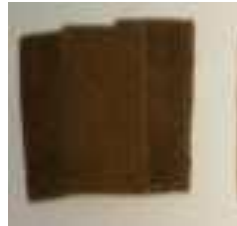

(a)

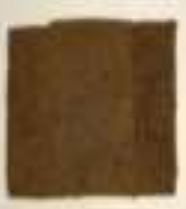

(b)

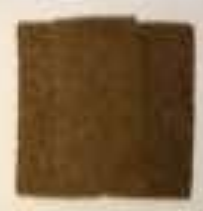

(c)
Gambar 1. Biskuit Campuran Bekatul Beras Merah dan Ubi Jalar Ungu. (a) = Formula 1; (b) = Formula 2; (c) = Formula 3

Tabel 2. Hasil Uji Organoleptik Biskuit

\begin{tabular}{|c|c|c|c|}
\hline \multirow[b]{2}{*}{ Formula } & \multicolumn{3}{|r|}{ Rata-rata } \\
\hline & Warna & Rasa & Aroma \\
\hline F1 & Cokelat & ++ & $\begin{array}{l}\text { Cokelat dengan khas } \\
\text { bekatul }\end{array}$ \\
\hline $\mathrm{F} 2$ & Cokelat & +++ & $\begin{array}{l}\text { bekatul } \\
\text { Cokelat dengan khas }\end{array}$ \\
\hline F3 & Cokelat & ++++ & bekatul \\
\hline $\begin{array}{l}\text { Keteranga } \\
++\quad: \\
+++\quad: \\
++++\end{array}$ & $\begin{array}{l}\text { n Parame } \\
\text { cukup ma } \\
\text { manis } \\
\text { sangat ma }\end{array}$ & $\begin{array}{l}r \text { Rasa : } \\
\text { is } \\
\text { is }\end{array}$ & \\
\hline
\end{tabular}

\section{Hasil Uji Hedonik Biskuit}

Berdasarkan hasil uji hedonik atau uji kesukaan panelis terhadap biskuit, diketahui bahwa : warna, rasa, dan aroma ketiga formula biskuit tidak berbeda nyata. Hal ini masih berkaitan dengan hasil uji organoleptiknya seperti terlihat pada Tabel 2. Kemudian hasil analisis uji hedonik biskuit menggunakan SPSS 17 dapat dilihat pada Tabel 3.

Tabel 3. Hasil Analisis Data Uji Hedonik Biskuit menggunakan SPSS 17

\begin{tabular}{lccc}
\hline & \multicolumn{3}{c}{ Rata-rata } \\
\cline { 2 - 4 } Formula & Warna & Rasa & Aroma
\end{tabular}

\begin{tabular}{llll}
\hline F1 & $3,50^{\mathrm{a}}$ & $3,15^{\mathrm{a}}$ & $3,15^{\mathrm{a}}$ \\
F2 & $3,50^{\mathrm{a}}$ & $3,45^{\mathrm{a}}$ & $2,95^{\mathrm{a}}$ \\
F3 & $3,50^{\mathrm{a}}$ & $3,35^{\mathrm{a}}$ & $3,00^{\mathrm{a}}$ \\
\hline
\end{tabular}

Catatan: Huruf yang sama pada superscript $\left({ }^{a}\right)$ pada kolom yang sama menunjukkan hasil yang tidak berbeda nyata.

Keterangan :

$\mathrm{F} 1$ = Formula 1, bekatul beras merah : ubi jalar ungu (20:40)

F2 = Formula 2, bekatul beras merah : ubi jalar ungu $(15: 45)$

F3 = Formula 3, bekatul beras merah : ubi jalar ungu (10:50)

Hasil analisis menunjukkan tidak ada pengaruh perbedaan formula terhadap parameter aroma $(\mathrm{P} 0,884>0,05)$, rasa $(\mathrm{P}$ $0,603>0,05)$, dan warna (P 1,000>0,05). Untuk menentukan formula terbaik maka dilakukan uji aktvitas antioksidan pada setiap formula biskuit, kemudian dilakukan pengujian serat pangan dan uji proksimat pada biskuit.

\section{Hasil Uji Aktivitas Antioksidan Hasil Penetapan Panjang Gelombang DPPH}

Penentuan penentuan panjang gelombang maksimum DPPH dilakukan pada kisaran 500-520 nm karena larutan DPPH yang berwarna ungu berada di daerah visible pada panjang gelombang 380-780 nm (Khopkar, 1990) atau panjang gelombang 480-570 nm (Gandjar, 2007). Dari hasil penentuan didapatkan panjang gelombang maksimum DPPH adalah 515 nm. Penetapan panjang gelombang maksimum dilakukan agar pengukuran aktivitas antioksidan selanjutnya menghasilkan kepekaan dan keakuratan yang lebih tinggi, daya serap relatif konstan sehingga dapat diperoleh kurva kalibrasi yang linear. Hasil penentuan panjang gelombang DPPH dapat dilihat pada Gambar 2 berikut ini: 


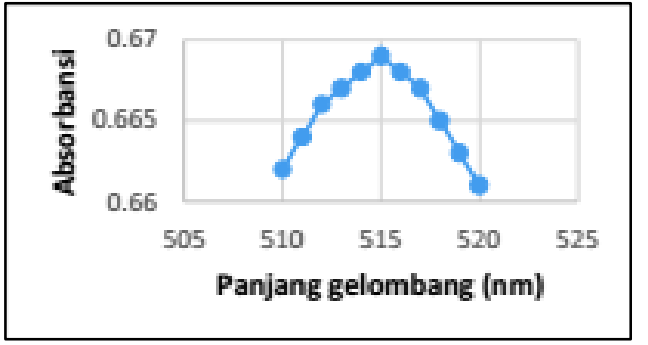

Gambar 2. Penentuan panjang gelombang maksimal DPPH

\section{Hasil Penetapan Waktu Inkubasi}

Penetapan waktu inkubasi ini bertujuan untuk mengetahui waktu yang dibutuhkan oleh suatu zat agar dapat bereaksi secara maksimal sehingga diperoleh nilai serapan yang stabil. Penetapan waktu inkubasi ini dilakukan menggunakan larutan standar vitamin $\mathrm{C}$ $100 \mathrm{ppm}$ dan penambahan larutan DPPH $1 \mathrm{mM} 1 \mathrm{~mL}$ dan diuji pada serapan $515 \mathrm{~nm}$ dan waktu inkubasinya ditunjukan pada menit ke 30. Waktu yang diperoleh tersebut sesuai dengan penelitian sebelumnya yaitu 30 menit (Mustikasari et al., 2012). Optimasi waktu inkubasi DPPH dapat dilihat pada Gambar 3.

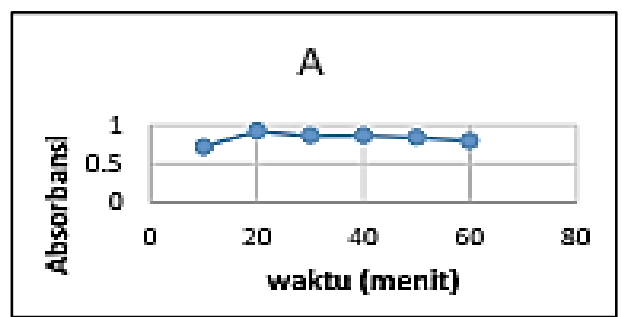

Gambar 3. Grafik Penetapan Waktu Inkubasi

\section{Hasil Pembuatan Deret Standar Larutan Vitamin C}

Dilakukan uii deret standar dengan dibuat beberapa konsentrasi diantaranya 2 , 4, 6, 8, dan $10 \mathrm{ppm}$. Sehingga diperoleh persamaan linear pada vitamin $\mathrm{C} \mathrm{y}=$ $4.9028 \mathrm{x}+22.904$ dengan nilai $\mathrm{R}^{2}=$ 0.9993 , analisis regesi dapat dipercaya apabila nilai $\mathrm{R}^{2}$ mendekati 1 . Nilai $\mathrm{R}^{2}$ yang diperoleh mendekati 1 , sehingga dapat digunakan untuk analisis selanjutnya. Standar yang digunakan vitamin $\mathrm{C}$, karena vitamin $\mathrm{C}$ memiliki potensi aktivitas antioksidan yang tinggi yaitu 3,87ppm (Mustikasari, et al., 2012). Deret larutan vitamin $\mathrm{C}$ dapat dilihat pada Gambar 4.

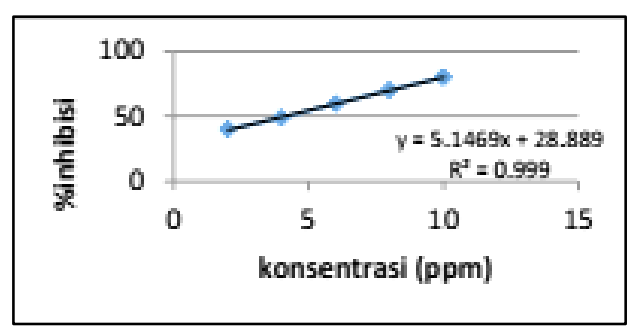

Gambar 4. Kurva Inhibisi Vitamin C

\section{Hasil Uji Aktivitas Antioksidan Sediaan Biskuit}

Aktivitas antioksidan sampel biskuit dan kontrol positif vitamin $\mathrm{C}$ dapat dilihat pada Tabel 4. Aktivitas antioksidan tertinggi didapatkan dari sampel biskuit yang dibuat menggunakan formula 1. Dari hasil pengukuran aktivitas antioksidan, bila dibandingkan dengan kontrol positifnya yaitu vitamin $\mathrm{C}$ maka dapat diketahui bahwa bekatul beras merah memiliki aktivitas antioksidan kuat sementara sediaan biskuit memiliki aktivitas antioksidan yang terbilang sedang.

Tabel 4. Aktivitas Antioksidan Bahan Baku dan Sampel

\begin{tabular}{|c|c|c|}
\hline Sampel & $\begin{array}{c}\text { Aktivitas } \\
\text { Antioksidan } \\
\text { (IC } \mathbf{5 0} \text { ppm) }\end{array}$ & Keterangan \\
\hline $\begin{array}{c}\text { Kontrol } \\
\text { (vitamin C) }\end{array}$ & 4,10 & Sangat kuat \\
\hline $\begin{array}{c}\text { Bekatul } \\
\text { beras merah }\end{array}$ & $\begin{array}{c}85,13 \\
2\end{array}$ & Kuat \\
\hline $\begin{array}{c}\text { Sampel } \\
\text { Biskuit (F1) }\end{array}$ & $\begin{array}{c}106,3 \\
49\end{array}$ & Sedang \\
\hline $\begin{array}{c}\text { Sampel } \\
\text { Biskuit (F2) }\end{array}$ & $\begin{array}{c}122,5 \\
20\end{array}$ & Sedang \\
\hline $\begin{array}{c}\text { Sampel } \\
\text { biskuit (F3) }\end{array}$ & 147,6 & Sedang \\
\hline
\end{tabular}

Bekatul beras merah yang diperoleh dari Pelabuhan Ratu memiliki nilai $\mathrm{IC}_{50}$ sebesar 85,132 ppm sedangkan sediaan biskuit dari Formula 1 ke Formula 3 
aktivitas antioksidannya semakin menurun. Kecendrungan ini terkait dengan konsentrasi bekatul beras merah pada setiap formula. Formula 1 merupakan formula yang mengandung bekatul beras merah paling banyak yaitu sebesar $20 \%$, kemudian formula 2 sebesar $15 \%$, dan formula 3 sebesar $10 \%$. Keterkaitan antara konsenrasi bekatul dan nilai antioksidan menunjukan bahwa senyawa-senyawa bersifat antioksidan lebih banyak terdapat pada bekatul dibandingkan dengan senyawa-senyawa antioksidan pada ubi ungu. Kemungkinan besar senyawa-senyawa pada bekatul yang bersifat antioksidan adalah fenolik dan antosianin yang disebutkan selain memberi pigmen pada bekatul beras merah juga membuat bekatul beras merah berpotensi sebagai antioksidan (Adzkiya, 2011). Hasil penelitian Tengah et al. (2011) juga menunjukan adanya korelasi linier antara kandugan fenolik dan kandungan antosianin beras merah terhadap aktivitas antioksidan yang dimiliki karena pada penelitiannya ditemukan bahwa semakin tinggi kandungan fenolik dan antosianin yang terdapat dalam bekatul beras merah maka semakin tinggi pula hasil aktivitas antioksidannya.

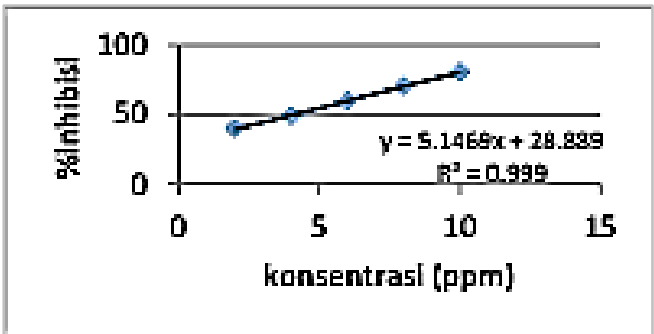

Gambar 5. Kurva Nilai $\mathrm{IC}_{50}$ Vitamin $\mathrm{C}$

Formula 1 merupakan formula dengan aktivitas antioksidan paling tinggi dengan nilai $\mathrm{IC}_{50} 106,349$ ppm, maka formula ini dipilih sebagai formula terbaik yang kemudian dilanjutkan pada uji kandungan serat dan uji proksimat. Kurva nilai $\mathrm{IC}_{50}$ Vitamin $\mathrm{C}$, bekatul beras merah, dan sampel biskuit formula 1, 2 dan 3 diperoleh berdasarkan kurva pada Gambar 5, Gambar 6, Gambar 7, Gambar 8 dan Gambar 9.

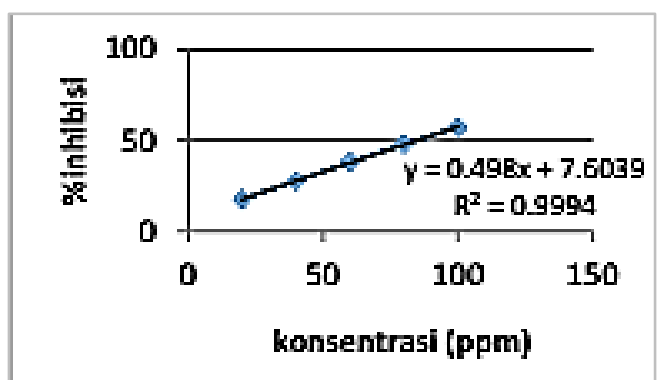

Gambar 6. Kurva Nilai $\mathrm{IC}_{50}$ Bekatul Beras Merah

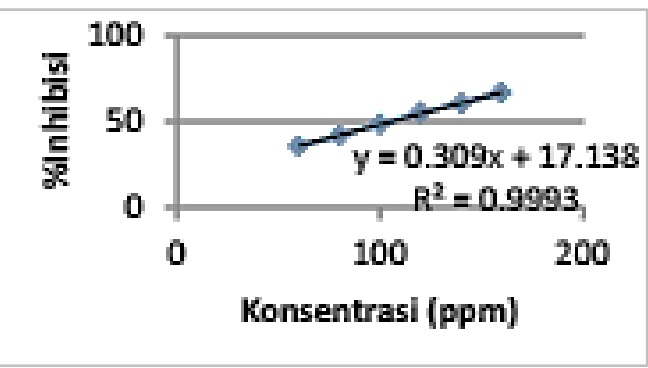

Gambar 7. Kurva Nilai $\mathrm{IC}_{50}$ Biskuit Formula 1

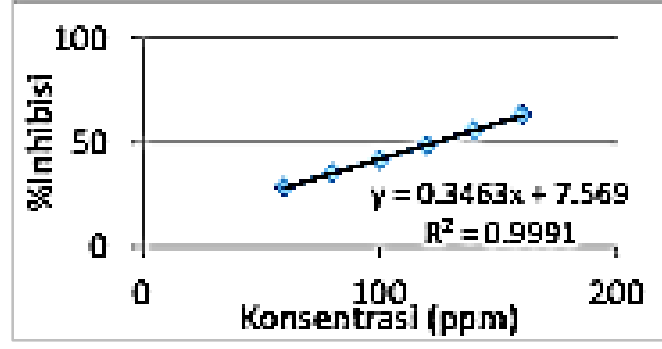

Gambar 8. Kurva Nilai $\mathrm{IC}_{50}$ Biskuit Formula 2

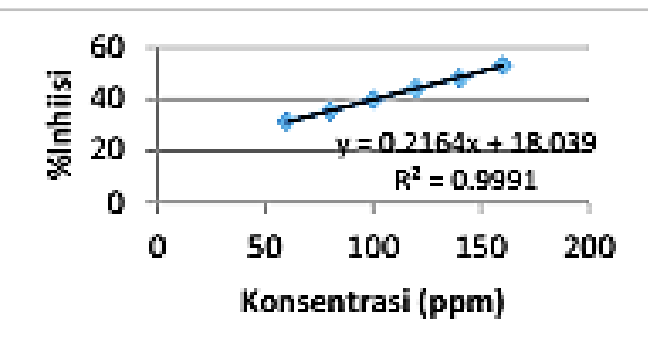

Gambar 9. Kurva Nilai $\mathrm{IC}_{50}$ Biskuit Formula 3

Hasil Uji Kadar Serat Pangan Sediaan 


\section{Biskuit}

Serat pangan atau "dietary fibre" mencakup seluruh bagian tanaman yang tidak dapat dicerna oleh enzim pencernaan manusia. Tanpa membedakan serat tersebut mengalami atau tidak mengalami proses pengolahan, tanpa melihat untuk kepentingan diet tanpa mempertimbangkan serat tersebut dapat atau tidak untuk dimakan. Kebutuhan serat pangan harian yang dianjurkan sebesar 30 gram/hari (Marsono, 1996). Hasil analisis kadar serat pangan dapat dilihat pada Tabel 5.

\section{Tabel 5. Hasil Analisis Kadar Serat} Pangan Biskuit F1 (20:40) F2 (15:45) F3(10:50)

\begin{tabular}{cccc}
\hline Kadar & & \\
$\begin{array}{c}\text { Serat Pangan } \\
(\%)\end{array}$ & 6,38 & 6,38 & 6,42 \\
\hline
\end{tabular}

Keterangan :

F1 = Formula 1, bekatul beras merah : ubi jalar ungu (20:40)

F2 = Formula 2, bekatul beras merah : ubi jalar ungu $(15: 45)$

F3 = Formula 3, bekatul beras merah : ubi jalar ungu (10:50)

Biskuit formula 1 dan formula 2 dengan perbandingan masing-masing bekatul beras merah : ubi jalar ungu (20:40 dan 15:45) memiliki kandungan serat yang sama yaitu $6.38 \%$, sedangkan formula 3 dengan perbandingan bekatul beras merah :ubi jalar ungu (10:50) memiliki kandungan serat yang paling tinggi yaitu $6.42 \%$. Perbandingan formula yang digunakan ubi jalar ungu lebih banyak dituangkan ke dalam campuran adonan dibanding dengan bekatul beras merah maka bisa jadi penyebab besarnya kadar serat pada setiap formula karena adanya peningkatan konsentrasi ubi jalar ungu yang ditambahkan. Formula mengandung konsentrasi ubi jalar ungu paling tinggi yaitu sebesar 50\%, sedangkan formula 2 sebesar $45 \%$, dan formula 1 sebesar $40 \%$. Penelitian Nintami (2012), yang membuat sediaan mi basah menyatakan bahwa substitusi tepung ubi jalar ungu secara bermakna meningkatkan kadar serat.

Menurut BPOM no. 13 tahun 2016 makanan kaya serat mangandung kadar serat pangan $6 \%$, sehingga semua formula biskiut campuran bekatul beras merah dan ubi jalar ungu telah memenuhi syarat makanan kaya serat dan zat gizi.

\section{Proksimat Biskuit}

Analisis proksimat bahan baku biskuit dilakukan terhadap 5 parameter uji yaitu kadar protein, lemak, karbohidrat, air dan abu.

\section{Kadar Protein Sediaan Biskuit}

Didapat kadar protein pada sampel formula 1 sebesar $6,93 \%$, di mana hasil tersebut sudah memenuhi syarat SNI tahun 2011 yaitu minimal 5\%. Kadar protein pada biskuit diperoleh dari sumber protein berupa telur, susu skim, mentega, tepung terigu, bekatul beras merah, serta ubi jalar ungu. Kadar protein merupakan parameter yang penting karena produk diharapkan selain memiliki rasa yang dapat diterima namun disertai nilai gizi yang dapat memenuhi nutrisi.

\section{Kadar Lemak Sediaan Biskuit}

Lemak memiliki banyak fungsi, salah satunya sebagai cadangan energi. SNI tahun 1992 menetapkan kadar lemak minimum biscuit sebesar 9\%. Kadar lemak rata-rata biskuit kombinasi dan ubi ungu formula 1 adalah 16,178\% sehingga biskuit terkategori telah memenuhi syarat SNI. Lemak pada biskuit diperoleh dari telur, mentega, dan susu skim yang ditambahkan pada formula adonan biskuit.

\section{Kadar Karbohidrat Sediaan Biskuit}

Karbohidrat merupakan sumber energi utama yang dibutuhkan tubuh untuk dapat melakukan aktivitas. Kadar 
karbohidrat yang diperoleh yaitu $72,625 \%$ sehingga akan memenuhi standar SNI tentang Mutu dan Cara Uji Biskuit tahun 1992 yang menetapkan kandungan karbohidrat minimum bahan olahan adalah $70 \%$. Karbohidrat pada formula biskuit didapat dari adanya tepung terigu, ubi jalar ungu, susu skim, cokelat bubuk, dan bekatul beras merah.

\section{Hasil Analisis Kadar Air Sediaan Biskuit}

Menurut Winarno (1997), kadar air dalam bahan makanan menentukan kesegaran dan daya awet makanan. Hasil pengukuran kadar air biskuit formula I diperoleh sebesar $2.525 \%$. Pengujian kadar air untuk formula 1 memenuhi syarat SNI tahun 2011 untuk biskuit yaitu maksimum 5\%. Rendahnya kadar air pada biskuit ini memberi keuntungan pada saat penyimpanan karena akan menghasilkan daya simpan yang lebih lama.

\section{Kadar Abu Sediaan Biskuit}

Pengabuan dan biasanya komponen yang terdapat pada senyawa anorganik alami adalah kalium, kalsium, besi, magnesium, dan mangan. Semakin tinggi kadar abu dari suatu bahan pangan menunjukkan tingginya kadar mineral dari bahan tersebut (Winarno, 2004). Hasil pengukuran kadar abu untuk biskuit Formula 1 sebesar $1,45 \%$ yang memenuhi syarat SNI 1992 yaitu kurang dari 4\%. Menurut Pratama et al. (2004), kadar abu akan dipengaruhi oleh adanya kandungan mineral-mineral awal dalam bahan baku. Kadar abu dalam suatu bahan menggambarkan banyaknya mineral yang tidak terbakar menjadi zat yang dapat menguap. Kadar abu yang dihasilkan berasal dari kandungan mineral yang terdapat pada bekatul beras merah dan ubi jalar ungu. Bekatul beras merah dan ubi jalar ungu memiliki kandungan mineral seperti kalsium, fosfor, dan zat besi.

\section{SIMPULAN DAN SARAN}

1. Aktivitas antioksidan pada formula terbaik sediaan biskuit campuran bekatul beras merah dan ubi jalar ungu dinyatakan sedang, yaitu formula 1 satu dengan nilai $\mathrm{IC}_{50}$ 106, 349 ppm. Aktivitas serat pangan pada formula 1 adalah sebesar $6,38 \%$, sedangkan yang tertinggi diperoleh pada Formula 3 dengan nilai $6,42 \%$.

2. Ketiga Formula biskuit dapat diterima oleh panelis. Perbedaan yang perbandingan bekatul beras merah dan ubi jalar ungu pada sediaan biskuit tidak mempengaruhi rasa, warna, dan aroma dari setiap formula.

\section{Saran}

1. Perlu dilakukan pengujian serat pada bekatul beras merah dan dilakukan pengujian untuk mengetahui kadar antosianin yang terdapat pada sediaan biskuit.

2. Perlu dilakukannya reformulasi untuk memperoleh aktivitas antioksidan dan serat pangan biskuit dengan mencampurkan bahan lain yang berpotensi sebagai zat antioksidan dan penambah serat pangan.

\section{DAFTAR PUSTAKA}

Adzkiya, M.A.Z. 2011. Kajian Potensi antioksidan beras merah dan pemanfaatannya pada minuman beras kencur. Thesis. Institut Pertanian Bogor. Bogor.

BPOM. 2005. Peraturan Kepala Badan Pengawas Obat dan Makanan Republik Indonesia tentang Ketentuan Pokok Pengawasan Pangan Fungsional. BPOM. Jakarta.

Badan Standarisasi Nasional. 1992. SNI 01-2973-1992: Syarat Mutu dan Cara Uji Biskuit. Jakarta.

\begin{tabular}{|c|c|}
\hline Dep & Kesehatan \\
\hline $\begin{array}{l}\text { Indonesia. } \\
\text { Indonesia }\end{array}$ & $\begin{array}{l}\text { 1980. Materia } \\
\text { Jilid }\end{array}$ \\
\hline
\end{tabular}


Direktorat Pengawasan Obat dan Makanan. Hal 77-185.

Departemen Perindustrian. 1990. Standar Industri (SII) Standar Mutu Biskuit (SII: 0177-90). Jakarta

Dyah, S. 2016. Perbandingan tepung kulit pisang ambon (Musa acuminate var. Colla) dengan bekatul sebagai pangan fungsional snack kaya serat. Skripsi. Universitas Pakuan. Bogor.

Gandjar, E.I.G. dan R. Abdul. 2007. Kimia Farmasi Analisis. Pustaka Pelajar. Yogyakarta. Hal 79-227.

Gardjito, M., Djuwardi, A., dan Harmayani, E. 2013. Pangan Nusantara. Penerbit Kencana. Jakarta.

Kumalaningsih, S. 2006. Antioksidan Alami: Penangkal Radikal bebas. Trubus Agisarana. Surabaya.

Manley, D. 2000. Technology of Biscuits, Crackers and Cookies. Woodhead Publishing Ltd. Cambridge.

Marsono, 1996. "Dietary Fibre" dalam Makanan dan Minuman Fungsional. Kursus Singkat Makanan Fungsional. PAU Pangan dan Gizi UGM. Yogyakarta.

Moko, E.M., Purnomo, H., Kusnadi, J., Ijong, F.G. 2014. Phytocemical content and antioxidant properties of colored and non-colored varieties of rice bran from Minahasa, North Sulawesi, Indonesia. International Food Research Journal 21(3): 10531059.

Mustikasari, V., Sutanto dan S. Wardatun. 2012. Potensi ekstrak daun binahong (Anredera condifolia (Ten) Steenis) sebagai antioksidan. Kumpulan Jurnal Farmasi. Program Studi Farmasi FMIPA Universitas Pakuan. Bogor. Hal 8-14.

Nintami, Ayudya L. 2012. Kadar serat, aktivitasaAntioksidan, amilosa dan uji kesukaan mi basah dengan substitusi tepung ubi jalar ungu (Ipomea batatas L.) bagi penderita diabetes melitus tipe 2. Skripsi. Program Studi Farmasi. Universitas Diponegoro. Semarang.

Pratama, R.I., I. Rositini dan E. Liviawaty, 2014. Karakteristik biskuit dengan penambahan tepung tulang ikan jungilus (Istiophorus Sp.) Jurnal Akuantika. 5(1):30-39.

SNI. 2011. Biskuit. Badan Standarisasi Nasional: 2973. Jakarta.

Tengah, I.G.P. 2011. Pengaruh Pengasaman dan Waktu Ekstraksi Terhadap Komponen Bioaktif serta Aktivitas Antioksidan Ekstrak Bekatul Beras Merah. Laporan Penelitian Hibah Unggulan Udayana.

Winarno, F. G dan F. Kartawijaya. 2007. Pangan Fungsional dan Minuman Energi. MBRIO PRESS. Bogor.

Wulandari, P. A., I.K. Suter, N.K. Putra, I.W.R. Widarta 2012. Bekatul Beras Merah Sebagai Salah Satu Alternatif Sumber Antioksidan. Jurnal Ilmu dan Teknologi Pangan. 1(1): 1 - 8 .

Wulandari, M. dan Handarsari 2010. Pengaruh Penambahan Bekatul Terhadap Kadar Protein dan Sifat Organoleptik Biskuit. $\underline{\text { Jurnal }}$ Pangan dan Gizi. 1(2): 55 - 62. 